\title{
Milk Price Comparison Between Six Years from Romania and European Union
}

\author{
Anamaria VÂTCĂ ${ }^{1}$, Anca ROTARU ${ }^{1 *}$, Ștefania GÂDEA ${ }^{2}$, Sorin VÂTCĂ², Valentina STOIAN²*
}

\begin{abstract}
${ }^{1}$ Faculty of Animal Husbandry and Biotechnology, University of Agricultural Sciences and Veterinary Medicine ClujNapoca, Calea Manastur no 3-5, Cluj, Cluj-Napoca, 400372, Romania

2 Faculty of Agriculture, University of Agricultural Sciences and Veterinary Medicine Cluj-Napoca, Calea Manastur no. 3-5, Cluj, Cluj-Napoca, 400372, Romania

* Corresponding author: A. Rotaru e-mail: ancuta.rotaru@usamvcluj.ro; V. Stoian e-mail: valentina.stoian@usamvcluj.ro
\end{abstract}

RESEARCH ARTICLE

\begin{abstract}
Milk price tendency is essential for the national economy and protection of milk producers. The constant need to align with European standards motivate this study to assess the interaction of milk prices in our country compared to the European Union. The objective of the study was to statistically compare the prices from Romania and UE. For a deep overview we took into consideration the quantity from Romania and most important qualitative milk parameters namely protein and fat content. The data was from 6 years from 2013 until 2018 and from all four seasons. Analysis of variance was performed together with mean comparisons between different years and seasons. Milk medium prices were higher with at least $20 \%$ in UE compared to Romania. Prices were higher in autumn and winter rather than in spring and summer proportionally with the quantity of milk. Protein and fat content was significantly higher in autumn and winter season.
\end{abstract}

Keywords: Milk price; protein; fat; change; strategy.

Received: 11 February 2021 Accepted: 19 April 2021 Published: 15 May 2021

DOI:

10.15835/buasvmcn-asb:2021.0003

\section{INTRODUCTION}

Understanding the tendency of price behavior is a critical element for the decision makers and some uncertain conditions could significantly influence the return of dairy market participants (Hansen and Li, 2017; Yang et al., 2019; Anggita and Ali, 2017). Unfortunatly, in Romania the protection policy for milk producers is not well developed and seems not to function primarily among subsistence livestock farms. For our country, primary milk production is a strategic product that provide food and economic income for the population (Panzaru and Medelete, 2018; Popescu and Angel, 2019). The milk production represents the second place after meat and animal production in zootehnical sector from almost all areas in Romania (Panzaru and Medelete, 2018). Some problems with milk price and other dairy products could be summarized by the appliance of some rate quotas to the price only at processed products like butter or milk powder, while European Union made a fully liberalized market for cheese (Panzaru and Medelete, 2018; Kalliovirta et al., 2019). The prices for agrifood products from Romania are usually set up following chain stage, market prices, the price system during previous periods of time and the price from the Common Market over years. The European Union established fixed prices for agricultural products based on an indicative price for transaction, the initial minimum level for the price at which 
products could be sold via import and the amount affordable for buy and store which is the guaranteed level for the price (Fousekis, 2018; Symeonidis and Tserkezos, 2020; Gulseven, 2018).

Setting up a price is a challenge and as well could be a complex action because of many companies and products diversity competition for the different consumers tastes (Xu et al. 2020; Amirnejad and Tonakbar, 2018). All agricultural and zootehnic products suffer fluctuation over time because of the emergence of inflationary factors, products perishability, specific storage needs, quality and quantity of consumer demands, therefore the term of market goods for existential consumption (Kharin et al., 2017). Taking for example other European countries such as Germany and Switzerland, in Germany is characterized by tariff-protected for dairy products prices except of cheese and at the milk producer prices for cheese are not linked with foreign prices level but with the industrial national production. In Switzerland, high-quality products are the only factor for the speed and difference of price transmission that can reduce international competition and pressure for price change via imposed tariffs (Hillen and von Cramon-Taubadel, 2019; Hanrahan et al. 2018). Increased variability for the milk price both in the world and especially in Romania territory, the world feed price during the last 10 years has increased the need for research on price dynamics and price forecasting (Hansen and $\mathrm{Li}$, 2017). There is a real need for a fair competitive market with a methodology that could diminish the risk to set an inefficient milk price base either too high or too low (Flux, 2020). A price that is too high could act as a barrier to economic efficiency (Borawski et al. 2020). It could be highlighted here that it could be a good idea to establish the milk price following a tested formula that should keep in account the content of fats and proteins for the raw dairy milk producers. Also, some studies tried to propose some adjustments including the milk volume and composition of fat which gives the milk profitability. Some recent price value increase was based on fat and protein relative ratio when evaluating farm system breed choice (Edwards et al. 2019). The aim of this paper was to explore the dynamics between 6 years of monthly milk medium prices from the European Union and Romania. The forecast of milk quantity and composition in terms of protein and fat from the Romanian collected milk were also tested.

\section{MATERIALS AND METHODS}

The data source was from EU communication after Regulation (EU) No. 2017/1185 Article 12(a), Annex II.4(a). Monthly medium price from Romania and Europe was analyzed based on seasonal change and trends between 6 years respectively 2013-2018. The milk price from Romania was in ROL and EURO for a better comparison between value changes. Other parameters taken into this study from Romania were the quantity of milk previously transformed from $\mathrm{kg}$ in millions of liters and the percent of protein and fat from raw dairy milk. The analysis was made between year, season and interaction or year and season for ANOVA, the seasons were abbreviated as follows: Sp for Spring season, Su for summer season, Au for autumn season, Wi for winter season and the years were 13 for 2013, 14 for 2014, 15 for 2015, 16 for 2016, 17 for 2017 and 18 for 2018.

All the data were analyzed in the software RStudio (R Studio Team, 2020) and R (R Core Team, 2019). We used the ANOVA and least significant difference (LSD) tests (Vâtcă et al., 2020; Vidican et al., 2020), which proved their performance in the assessment of variations in large databases, based on multiple factors. The two packages used are "psych" (Revelle, 2018), for basic statistics and "agricolae" (de Mendiburu, 2021) for ANOVA and LSD.

\section{RESULTS AND DISCUSSIONS}

Market tendency regarding medium price per liter registered significant growth $(P<0.001)$ in the cold season in Romania and in European Union the significant differences were seen over the years $(P<0.05)$ (Table 1$)$.

Table 1. Analysis of variance (ANOVA) for comparison between the price expressed in euro from Romania and European Union as effect of season and year change

\begin{tabular}{ccccc}
\hline & \multicolumn{2}{c}{ Price from Romania (euro) } & \multicolumn{2}{c}{ Price from European Union (euro) } \\
\hline F & P value & F & $P$ value \\
\hline Season & 0.10 & 0.753 & 6.86 & $P<0.05$ \\
\hline Year x Season & 10.36 & $P<0.001$ & 1.25 & 0.300 \\
\hline
\end{tabular}

European Union medium milk price was higher than in Romania as a general observation, the maximum limit was set at 0.40 euro in December 2013 and the minimum value of 0.34 in March in the same year. In Romania, raw milk price from 2013 follows the maximum price trend from December with a minimum value in June during summer 
based on a high milk quantity collected during this season. The difference between the prices from both compared regions shows that in Romania the price was with a minimum 20\% lower than in European Union.

By comparing the price tendency between years and seasons from Romania, we observe that the value of medium milk price decreased significantly from spring season of the year 2013 compared with the same season of the years 2015 and 2016 and increased significantly only in spring 2014 (Figure 1).

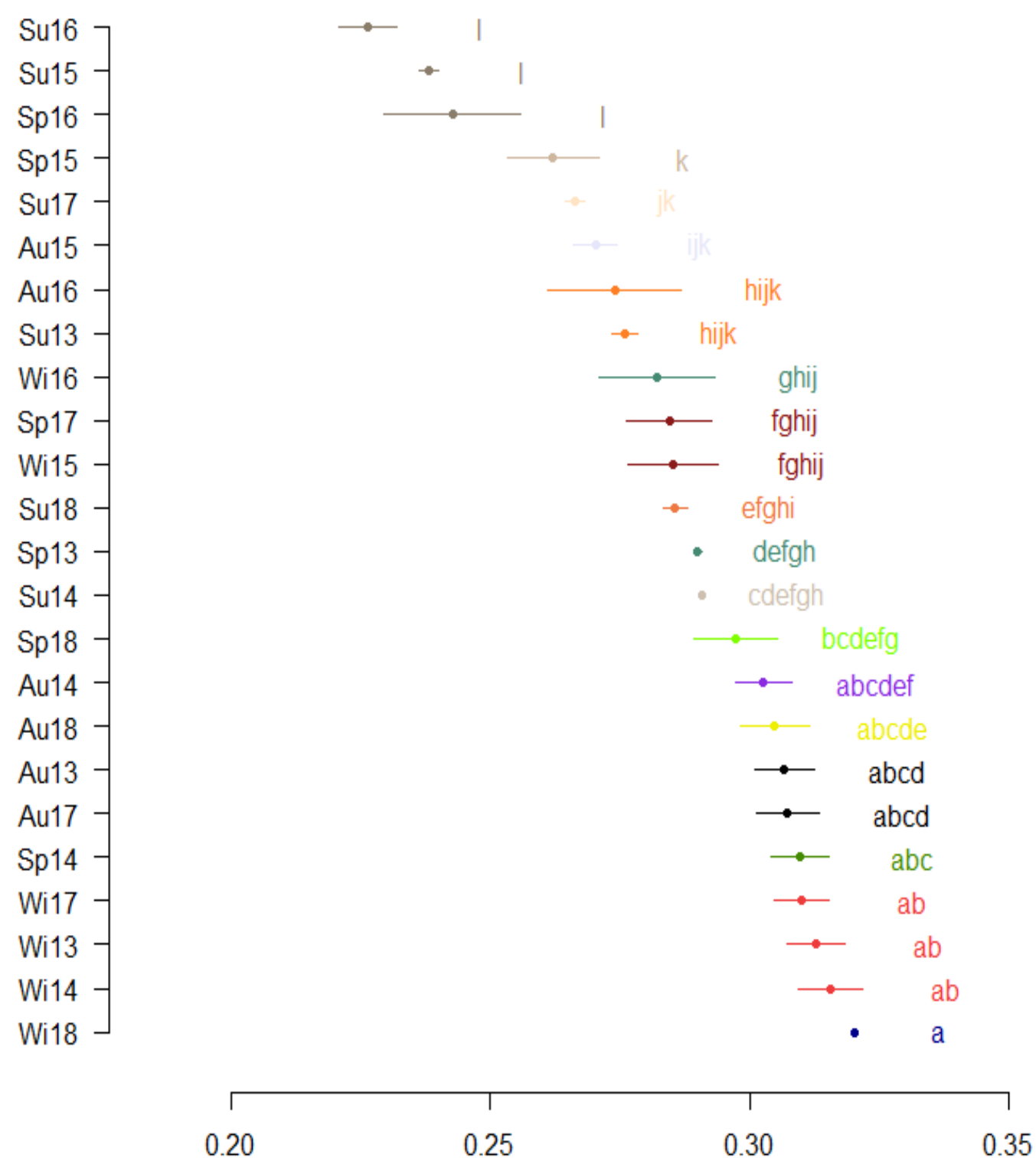

Figure 1. Milk price from Romania converted in euro (mean \pm S.E., LSD significance level at $P<0.05$ )

Significant lower price values were observed in summer, autumn and winter, in Romania between 2013 year and 2015-2016 period (LSD, $P<0.05$ ). The lowest medium milk prices in Romania were registered in spring and summer of the years 2015 and 2016 with significant differences among all other compared years (Figure 1).

If we compare the prices from Romania with the UE, it was observed a significant difference with higher values in UE in autumn and spring seasons of 2015 and 2016. Regarding the summer season significant higher differences were noticed in UE in the years 2015, 2016 and 2018. The winter season highlights only significant differences between both regions, superior price was as well set up in UE. 
In European Union, we can discuss as well as before the differences between years and seasons, taking into account the reference starting year 2013 from which we have the set of dates. Therefore, the evolution of medium milk price showed a decrease in 2015, 2016 and an increase in 2014 compared with the price from 2013 in the spring season. Lower significant milk price was registered in summer of the time interval 2015-2018 compared with the reference year 2013 (Figure 2).

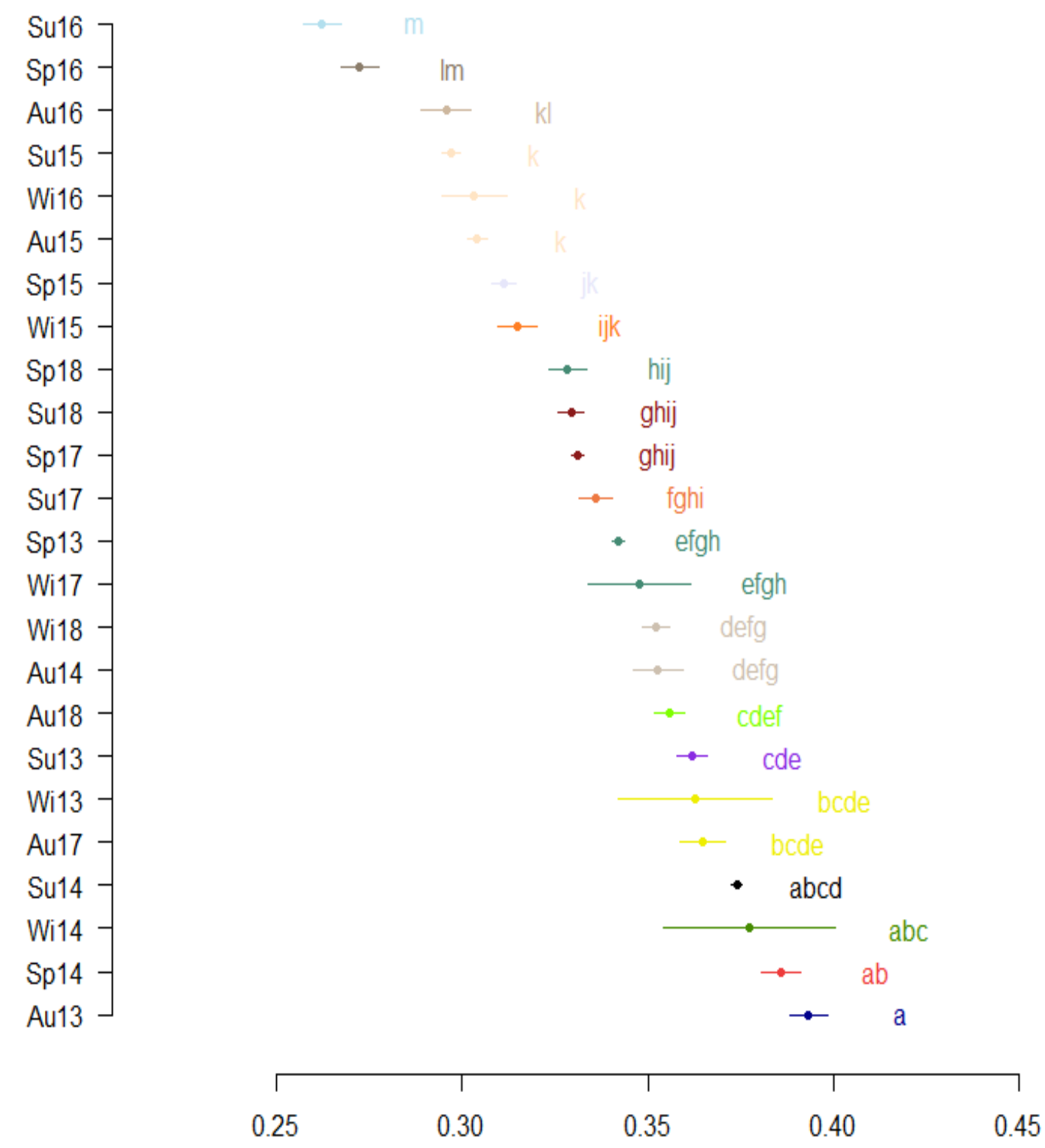

Figure 2. Milk price from European Union in euro (mean \pm S.E., LSD significance level at $P<0.05$ ).

The autumn season of 2013 was much homogeneous in trend prices and all other values were significantly decreased, so this year could be characterized as a year with high economic efficiency if we consider the medium milk prices. The values from the winter season showed significant differences with a decrease of milk medium price in the period of 2015-2017 compared with 2013.

Raw milk quantities registered in Romania had the highest value in summer season of 2014 and 2018 and the opposite values in winter 2013, 2014 (Figure 3). 


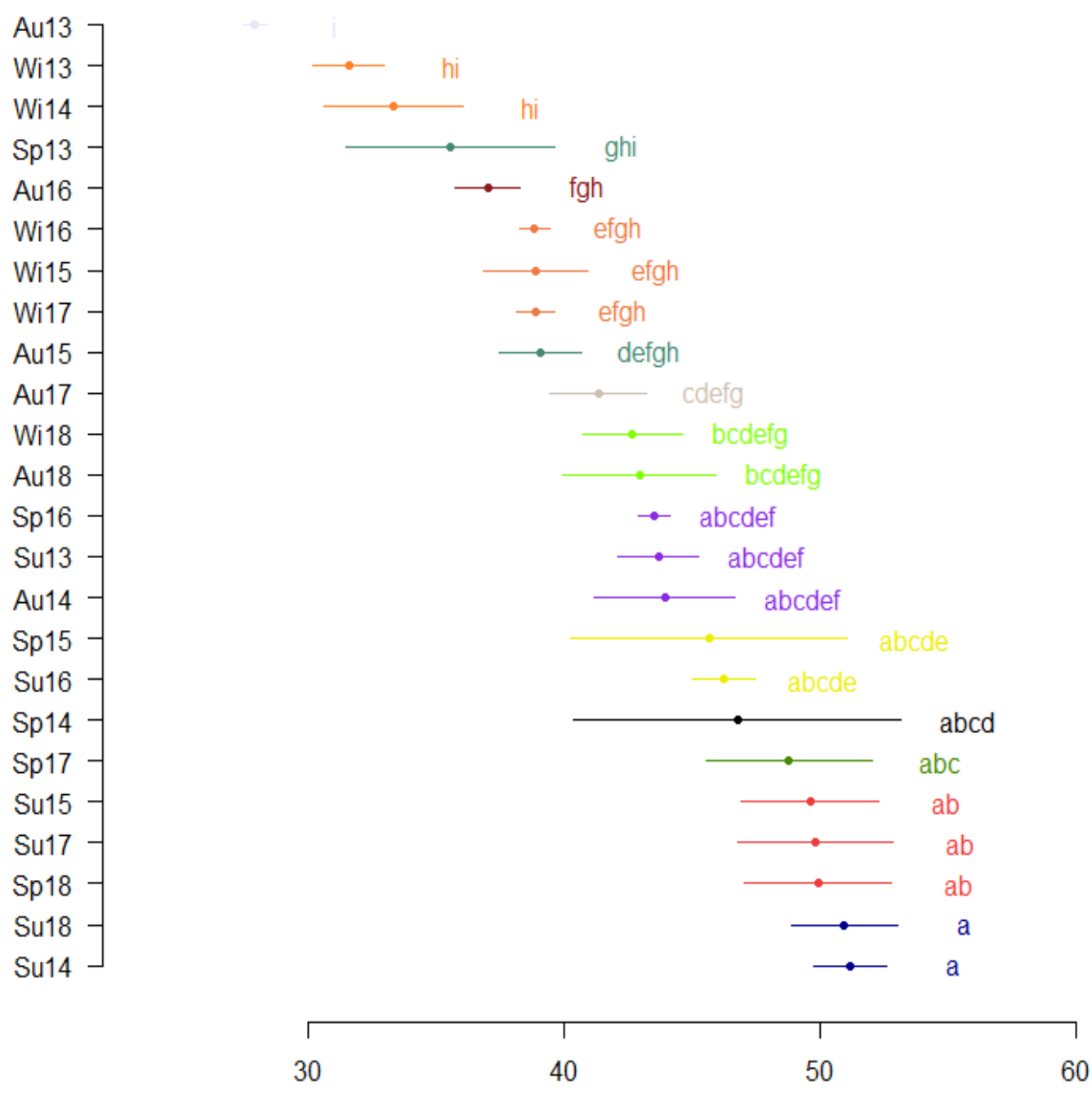

Figure 3. Milk quantity produced in Romania in millions of liters (mean \pm S.E., LSD significance level at $P<0.05$ )

Milk medium price was significantly higher in the summer of 2014 compared with autumn and spring of 2018 . The highest milk quantity from the reference year 2013 was observed in July in the summer season and the lowest value was in autumn at the transition to winter.

The total collected quantity was very significant depending on year and season $(P<0.001)$ (Table 2). Milk protein percent was significantly influenced by season and milk fat percent was significantly correlated with the year $(P=0.001)$ and season $(P<0.001)$.

Table 2. Analysis of variance (ANOVA test) of total collected milk quantity, protein and fat by season and year

\begin{tabular}{ccccccc}
\hline & \multicolumn{2}{c}{ Milk quantity } & \multicolumn{2}{c}{ Protein } & \multicolumn{2}{c}{ Fat } \\
\hline & F & $\boldsymbol{P}$ value & F & P value & F & P value \\
\hline Year & 24.07 & $P<0.001$ & 3.10 & 0.083 & 12.03 & 0.001 \\
\hline Season & 19.38 & $P<0.001$ & 34.78 & $P<0.001$ & 46.65 & $P<0.001$ \\
\hline Year x Season & 0.76 & 0.519 & 0.81 & 0.493 & 1.52 & 0.218
\end{tabular}

The highest content of protein in raw milk was in October for the reference year 2013, perhaps due to the quality of silage. The lowest protein content from collected milk was seen in July; summer season a reliable reason could be the climatic conditions of that period. In the spring, summer and winter seasons no significant changes in protein 
content happen between years (Table 3). Autumn had significant differences between the 2013 and 2014-2015 period.

The fat content did not differ significantly only in the winter season from 2014 compared with 2016-2017 (Table 4). The highest registered value of fat percent from milk was in January in the reference year 2013 for about 3.95\% and this growth was influenced by the continuous and constant and high-quality feed. The lowest value of the milk fat was noticed in the summer season when the livestock animals consume a high quantity of water because of an increased temperature in the atmosphere.

Table 3. Changes and evolution of milk protein content expressed in percent of the total quantity in all 6 years and seasons (LSD test, $P<0.05$ )

\begin{tabular}{ccccc}
\hline $\begin{array}{c}\text { Year } / \\
\text { Season }\end{array}$ & Spring & Summer & Autumn & Winter \\
\hline $\mathbf{2 0 1 3}$ & $3.3 \pm 0.01^{\text {defgh }}$ & $3.27 \pm 0.02^{\text {fghi }}$ & $3.49 \pm 0.04^{\mathrm{a}}$ & $3.38 \pm 0.03^{\mathrm{bc}}$ \\
\hline $\mathbf{2 0 1 4}$ & $3.26 \pm 0.02^{\mathrm{ghi}}$ & $3.26 \pm 0.01^{\mathrm{ghi}}$ & $3.36 \pm 0.04^{\mathrm{bcde}}$ & $3.36 \pm 0^{\mathrm{bcde}}$ \\
\hline $\mathbf{2 0 1 5}$ & $3.29 \pm 0.01^{\text {fgh }}$ & $3.24 \pm 0.02^{\mathrm{hi}}$ & $3.32 \pm 0.02^{\text {cdefg }}$ & $3.36 \pm 0.03^{\mathrm{cde}}$ \\
\hline $\mathbf{2 0 1 6}$ & $3.28 \pm 0^{\mathrm{fghi}}$ & $3.24 \pm 0^{\mathrm{hi}}$ & $3.43 \pm 0.04^{\mathrm{ab}}$ & $3.33 \pm 0.03^{\text {cdef }}$ \\
\hline $\mathbf{2 0 1 7}$ & $3.28 \pm 0.01^{\text {fghi }}$ & $3.22 \pm 0^{\mathrm{i}}$ & $3.36 \pm 0.03^{\mathrm{bcde}}$ & $3.38 \pm 0.03^{\mathrm{bc}}$ \\
\hline $\mathbf{2 0 1 8}$ & $3.27 \pm 0.02^{\text {fghi }}$ & $3.27 \pm 0.01^{\text {fghi }}$ & $3.37 \pm 0.03^{\mathrm{bcd}}$ & $3.37 \pm 0.03^{\mathrm{bcd}}$ \\
\hline
\end{tabular}

Note: Means followed by different letters indicate differences at $P<0.05$ according to LSD test. All data were subjected to the post-hoc comparison, and this permitted the interpretation both on vertical (Year) and horizontal (Season) planes.

Table 4. Changes and evolution of milk fat content expressed in percent of the total quantity in all 6 years and seasons (LSD test, $P<0.05$ )

\begin{tabular}{ccccc}
\hline $\begin{array}{c}\text { Year } / \\
\text { Season }\end{array}$ & Spring & Summer & Autumn & Winter \\
\hline $\mathbf{2 0 1 3}$ & $3.78 \pm 0.01^{\text {efgh }}$ & $3.69 \pm 0.02^{\text {ijk }}$ & $3.73 \pm 0.03^{\text {ghijk }}$ & $3.88 \pm 0.04^{\mathrm{abc}}$ \\
\hline $\mathbf{2 0 1 4}$ & $3.74 \pm 0.02^{\text {ghij }}$ & $3.65 \pm 0.01^{\mathrm{k}}$ & $3.80 \pm 0.03^{\text {cdefg }}$ & $3.84 \pm 0.01^{\mathrm{bcdef}}$ \\
\hline $\mathbf{2 0 1 5}$ & $3.76 \pm 0.01^{\text {fghi }}$ & $3.66 \pm 0.00^{\mathrm{jk}}$ & $3.86 \pm 0.05^{\mathrm{abcde}}$ & $3.86 \pm 0.03^{\mathrm{abcde}}$ \\
\hline $\mathbf{2 0 1 6}$ & $3.80 \pm 0.01^{\text {defg }}$ & $3.74 \pm 0.00^{\text {ghij }}$ & $3.79 \pm 0.05^{\text {cdefg }}$ & $3.93 \pm 0.01^{\mathrm{a}}$ \\
\hline $\mathbf{2 0 1 7}$ & $3.75 \pm 0.03^{\text {ghi }}$ & $3.70 \pm 0.00^{\text {hijk }}$ & $3.87 \pm 0.04^{\text {abcd }}$ & $3.94 \pm 0.01^{\mathrm{a}}$ \\
\hline $\mathbf{2 0 1 8}$ & $3.79 \pm 0.04^{\text {defgh }}$ & $3.70 \pm 0.02^{\text {hijk }}$ & $3.86 \pm 0.04^{\text {abcde }}$ & $3.93 \pm 0.01^{\mathrm{ab}}$ \\
\hline
\end{tabular}

Note: Means followed by different letters indicate differences at $P<0.05$ according to LSD test. All data were subjected to the post-hoc comparison, and this permit the interpretation both on vertical (Year) and horizontal (Season) plane.

\section{CONCLUSIONS}

Milk medium price was significantly high in the cold season in Romania and significantly low in the summer season. The only significant differences were based on the season.

In European Union the significant differences were seen over the years with the highest value in the reference year 2013 and autumn season.

Both regions had an increased milk price in December because of the highest care measures and low milk quantity in the winter season. The lowest prices from Romania were in summer season and in UE in spring season respectively.

The milk quantity was significantly higher if year and season were individually analyzed, with the highest values in 2014 and 2018 and lowest values in 2013 and 2014. As well it can be seen a similar tendency of increased milk quantity during summer and lower milk quantity in the winter season. The protein content from the collected milk differed significantly only in the autumn season between 2013 year and all other years except 2016. Milk fat content differed significantly in autumn season (2013 and 2017-2018) and winter season (2014 and 2016-2017). 
Author Contributions: Individual contributions of all authors: A.V. Conceived and designed the analysis; A.V. and S.V. Collected the data; V.S. Contributed data or analysis tools; V.S. Performed the analysis; A.V., A.R. and Ș.G. Wrote the paper.

\section{Conflicts of Interest}

The authors declare no conflict of interest.

\section{REFERENCES}

1. Amirnejad H, \& Tonakbar P. The willingness to pay for organic milk by consumers in Tehran. 2018

2. Anggita R, \& Ali $H$. The influence of product quality, service quality and price to purchase decision of SGM bunda milk (Study on PT. Sarihusada Generasi Mahardika Region Jakarta, South Tangerang District). Scholars Bulletin. 2017; 3(6):261-272.

3. Bolotova YV. An analysis of milk pricing in the United States dairy industry. Agribusiness. 2017; 33(2):194-208.

4. Borawski P, Guth M, Truszkowski W, Zuzek D, Beldycka-Borawska A, Mickiewicz B, ... \& Dunn JW. Milk price changes in Poland in the context of the Common Agricultural Policy. Agricultural Economics. 2020; 66(1):1926.

5. de Mendiburu F. 2019, Agricolae: Statistical Procedures for Agricultural Research. R package version 1.3-1. https://CRAN.R-project.org/package=agricolae

6. Edwards JP, Spaans OK, Neal M, \& Macdonald KA. Milk fat payment affects the relative profitability of Jersey and Holstein-Friesian cows at optimal comparative stocking rate. J Dairy Sci. 2019; 102(10):9463-9467.

7. Flux, A. Commission releases draft report on Fonterra's milk price; 2019.

8. Fousekis P. Price interrelationships in the EU cow milk markets: Evidence from rank-based cointegration tests. Outlook on Agriculture. 2018; 47(2):101-107.

9. Gulseven, O. Estimating factors for the demand of organic milk in Turkey. Br Food J. 2018; 120(2).

10. Hanrahan L, McHugh N, Hennessy T, Moran B, Kearney R, Wallace M \& Shalloo L. Factors associated with profitability in pasture-based systems of milk production. J Dairy Sci. 2018; 101(6):5474-5485.

11. Hansen BG \& Li Y. An analysis of past world market prices of feed and milk and predictions for the future. Agribusiness. 2017; 33(2):175-193.

12. Hillen J \& von Cramon-Taubadel S. Protecting the Swiss milk market from foreign price shocks: Public border protection vs. quality differentiation. Agribusiness. 2019; 35(4):516-536.

13. Kalliovirta L, Niskanen 0 \& Heikkilä AM. Forecasting milk prices with VAR models-Application to farm gate price in Finland. 2019, Available at SSRN 3473862.

14. Kharin, S., Lajdova, Z., \& Bielik, P. Price transmission on the Slovak dairy market. Studies in Agricultural Economics, 2017, 119(3), 148-155.

15. Panzaru RL \& Medelete DM. The evolution of milk purchase price in Romania. Evolution. 2018; 18(4).

16. Popescu A \& Angel E. Cow raw milk quality and its factors of influence in relationship with milk price. Scientific Papers: Management, Economic Engineering in Agriculture \& Rural Development. 2019; 19(1).

17. R Core Team, 2019. R: A language and environment for statistical computing. R Foundation for Statistical Computing, Vienna, Austria. URL https://www.R-project.org/.

18. Regulation (EU) No 2017/1185 Article 12(a) - Annex II.4(a) (prices of raw milk at real fat and protein content paid to milk producers) Data complete up to April $2020 \mathrm{https://ec.europa.eu/info/sites/info/files/food-}$ farming-fisheries/farming/documents/eu-raw-milk-prices en.pdf

19. Revelle W. 2018 psych: Procedures for Personality and Psychological Research, Northwestern University, Evanston, Illinois, USA, https://CRAN.R-project.org/package=psych Version $=1.8 .12$

20. RStudio Team, 2020. RStudio: Integrated Development for R. RStudio, PBC, Boston, MA URL http://www.rstudio.com/.

21. Symeonidis F \& Tserkezos D. Greek milk price decomposition. IJDSRM. 2020; 9(1-2):55-82.

22. Vâtcă S, Vidican R, Gâdea Ș, Horvat M, Vâtcă A, Stoian VA and Stoian V. Blackcurrant variety specific growth and yield formation as a response to foliar fertilizers. Agronomy. 2020; 10(12), p. 2014.

23. Vidican R, Păcurar F, Vâtcă SD, Pleșa A and Stoian V. Arbuscular mycorrhizas traits and yield of winter wheat profiled by mineral fertilization. Agronomy. 2020; 10(6), p. 846.

24. Xu L, Yang X \& Wu L. Consumers' willingness to pay for imported milk: Based on Shanghai, China. Int J Environ Res Public Health. 2020; 17(1):244.

25. Yang Y, Huisman W, Hettinga KA, Liu N, Heck J, Schrijver GH, ... \& van Ruth SM. Fraud vulnerability in the Dutch milk supply chain: Assessments of farmers, processors and retailers. Food Control. 2019; 95:308-317. 